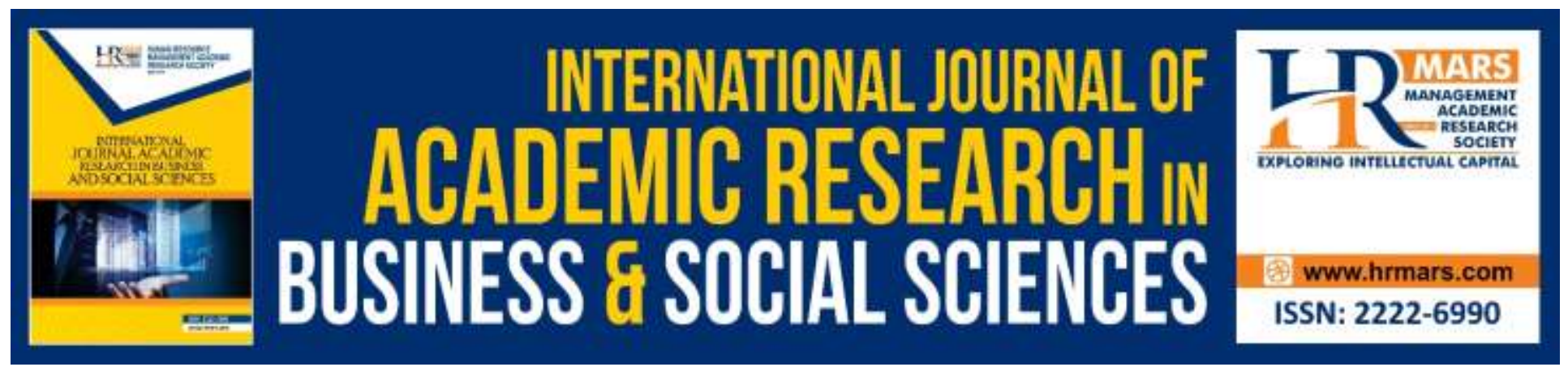

\title{
The Relationship between the Ulama and Malay Intellectuals in the Development of Islamic Education in Perak, 1922-1999
}

Nor Adina Abdul Kadir, Mohd Farhan Abd Rahman \& Mohamad Shafiei Ayub

To Link this Article: http://dx.doi.org/10.6007/IJARBSS/v10-i4/7151

DOI:10.6007/IJARBSS/v10-i4/7151

Received: 09 February 2020, Revised: 10 March 2020, Accepted: 28 March 2020

Published Online: 26 April 2020

In-Text Citation: (Kadir et al., 2020)

To Cite this Article: Kadir, N. A. A., Rahman, M. F. A., \& Ayub, M. S. (2020). The Relationship between the Ulama and Malay Intellectuals in the Development of Islamic Education in Perak, 1922-1999. International Journal of Academic Research in Business and Social Science, 10(4), 495-508.

Copyright: (C) 2020 The Author(s)

Published by Human Resource Management Academic Research Society (www.hrmars.com)

This article is published under the Creative Commons Attribution (CC BY 4.0) license. Anyone may reproduce, distribute, translate and create derivative works of this article (for both commercial and non-commercial purposes), subject to full attribution to the original publication and authors. The full terms of this license may be seen at: http://creativecommons.org/licences/by/4.0/legalcode

Vol. 10, No. 4, 2020, Pg. 495 - 508

http://hrmars.com/index.php/pages/detail/IJARBSS

JOURNAL HOMEPAGE

Full Terms \& Conditions of access and use can be found at http://hrmars.com/index.php/pages/detail/publication-ethics 


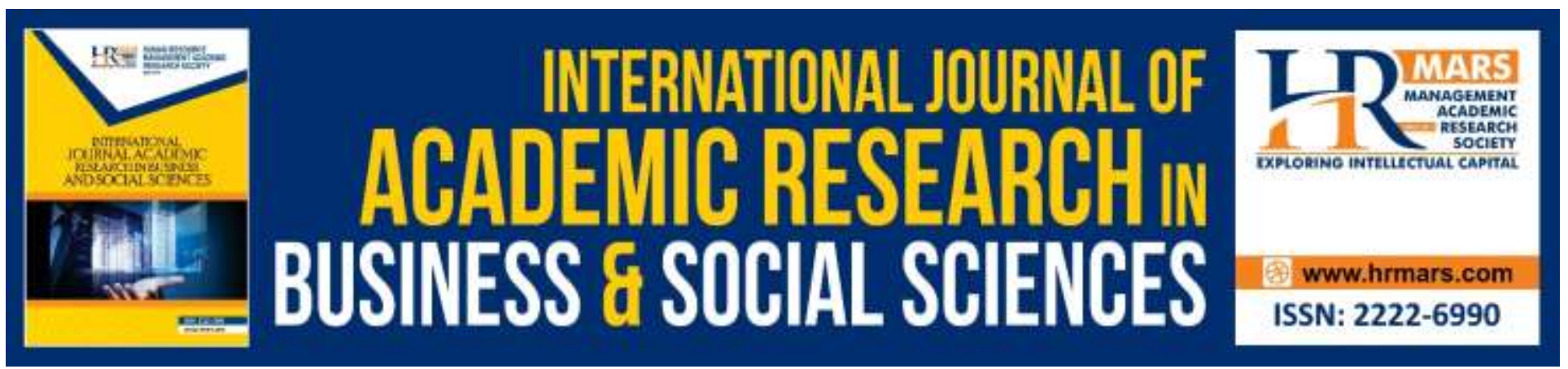

\title{
The Relationship between the Ulama and Malay Intellectuals in the Development of Islamic Education in Perak, 1922-1999
}

\section{Nor Adina Abdul Kadir ${ }^{1}$, Mohd Farhan Abd Rahman² \& Mohamad Shafiei Ayub ${ }^{1}$}

${ }^{1}$ Academy of Contemporary Islamic Studies (ACIS), MARA University of Technology (UiTM) Melaka Branch, Alor Gajah Campus, 78000 Alor Gajah, Melaka, Malaysia, ${ }^{2}$ Academy of Contemporary Islamic Studies (ACIS), MARA University of Technology (UiTM) Perak Branch, Seri Iskandar Campus, 32610 Seri Iskandar, Perak, Malaysia

\begin{abstract}
The ulama have played an important role in the intellectual development in the Malay Archipelago. They have significantly and meaningfully contributed in spreading knowledge, confirming to the foundation of Islamic teachings, which is fundamentally the emphasis of knowledge. History has shown that the involvement of Malay ulama when it comes to their writings as well as their role in the development of educational institutions have left a major impression on the excellence of the Malay community civilization in Malay Archipelago. As such, this paper will be focusing on the role and contribution of Malay ulama in the educational and intellectual development in Perak, especially in Madrasah Idrisiah Bukit Chandan Kuala Kangsar Perak. The establishment and development of Madrasah Idrisiah were closely related to the role of sultan and a number of prominent ulama who were the catalysts to the intellectual development of the madrasa. Based on this, the study will attempt to highlight the role of the respective ulama, as they were also very influential and proactive in the propagation of Islam in Perak.
\end{abstract}

Keywords: Madrasah Idrisiah, Ulama, Islamic Educational Development, 1922-1999

\section{Introduction}

This article is about the development of Islamic Education upon the role of ulama and intellectual relationship in the Malay intellectual in Perak. At the outset, it will explore the significant Malay Muslim civilization as well as the major role play by ulama and Malay intellectual in the development of Muslim civilizations in Malays Archipelago. Besides, for the specific purpose, it will concentrate on several issues about the main focus, namely: establishment Madrasah Idrisiah, the ulama and Kaum Muda discourse in 1922, the development of Islamic Education in Perak. 
INTERNATIONAL JOURNAL OF ACADEMIC RESEARCH IN BUSINESS AND SOCIAL SCIENCES Vol. 10, No. 4, April, 2020, E-ISSN: 2222-6990 @ 2020 HRMARS

The ulama in the Malay world have played an important role in the development of knowledge and intellect. Their contributions did only lie in the oral propagation to the community, but they have also produced valuable works that have served as a legacy of knowledge, which since then have been passed down to the next generation.

Additionally, the Malay ulama were also active in ensuring the continuity of education by establishing madrasas. The system of education in the Malaya began in the early $19^{\text {th }}$ century or the late $18^{\text {th }}$ century with influences from Patani, Sumatra, Java and Acheh. The teaching method was based on the method practiced at the Sacred Mosque in Makkah.

Since the time Islam was established in the Malay World, many Malay Muslims travelled to Makkah and Madinah for the obligatory pilgrimage or hajj. In addition to performing the hajj, there were also those who travelled to obtain and further their knowledge of Islam. This is because Makkah has been the gathering place for Islamic scholars and the center of Islamic civilization (Ghani, 2006). Thus, with the knowledge gained in Makkah and Madinah, the benefits were spread through the role and contributions of the Malay ulama once they returned home.

Madrasah Idrisiah also managed to gather a number of well-respected ulama who advised the rulers to love the people and the religion. Masjid Ubudiah or the Ubudiah Mosque, which was a landmark of religious height, recorded a significant event in history, where the late Sultan Iskandar Shah Qaddasallah consented to give lectures to cadis and muftis once a month (Nor, 2000). His concern for Islamic education made a significant contribution to the appreciation of Islam in society. The scholars often advised him on matters related to Islam.

\section{A Short History of the Establishment of Madrasah Idrisiah}

A prominent figure in the history of Madrasah Idrisiah was His Majesty the Sultan of Sultan Idris Mursyidul Adzam Shah who ruled from 1887 - 1916. He was the son of the late Raja Iskandar Ibni Raja Kechil Tengah Ahmad Ibni Almarhum Sultan Abdul Malik Mansur Shah (Adil, 1972). The sultan was born in Kuala Keboi, Kampar Perak in 1849 and was the $28^{\text {th }}$ sultan of Perak according to the sultanate genealogy of the State of Perak (Abdullah, 1999). He was elected as the sultan and settled in Istana Iskandariah Bukit Chandan Kuala Kangsar in July 1887 at the age of 38, when Sir Hugh Low was the Resident of Perak.

During his reign, education in Perak grew rapidly and he cared deeply about education and Islamic education in the state. In terms of governance, he was a prime mover in strengthening the institution and power of the Malay kings. On July 1, 1896, the four-state Conference of the Malay Kings or Durbar (Perak, Selangor, Pahang and Negeri Sembilan) held a meeting at the Istana Iskandariah, chaired by Sir Charles Mitchell, the High Commissioner for the Allied Malay States at that time (Emerson, 1982). Because Sultan Idris was aware of the importance of knowledge to his people, he encouraged the establishment of schools in the state of Perak such as the Kuala Kangsar Malay College (1905), King Edward VII School, Taiping (1906) and the Malay Teachers College, Matang.

Aside from encouraging Malay children to receive proper education, Sultan Idris was also well known for paying attention to Islam. Apart from mosques, religious schools were also built on his command. Madrasah Idrisiah was founded in 1917 and started its operation in April 1922 or 1342 Hijrah (Zainuddin, 2000). It was the first religious school established in the state of Perak Darul Ridzuan and was the only school to implement the modern school education system and had a boarding school system at that time. Its establishment was based on the order of His Royal Highness 
INTERNATIONAL JOURNAL OF ACADEMIC RESEARCH IN BUSINESS AND SOCIAL SCIENCES Vol. 10, No. 4, April, 2020, E-ISSN: 2222-6990 @ 2020 HRMARS

Sultan Idris I Mursyidul Adzam Shah, the $28^{\text {th }}$ Sultan of Perak. The location chosen for the school was Bukit Chandan Kuala Kangsar and opposite Masjid Ubudiah, which is the earliest mosque to be built and has been the symbol of grandeur and Islamic civilization of Perak. The name Idrisiah was based on the name of Sultan Idris who was the founder of the school. Most importantly, it showed the role of the royals in building systematic religious schools at the time.

The establishment of Idrisiah was closely linked to the role of ulama such as the late Sheikh Haji Nawawi bin Haji Tahir (Pak Wi), who lead a sultan's hope institution. Before the madrasa got its name it was known as Madrasah Mariah, an institution that provided early education only to orphan girls in Perak. The madrasah was the catalyst for the establishment of a more prestigious school and eventually these two institutions, Madrasah Mariah and Madrasah Idrisiah, were placed under separate administrations. It was erected on the land of waqf which had been gifted by the queen of Sultan Idris, Her Royal Highness Utih Mariah. However, with increasing demand from the local people for the school to be opened to boys as well, His Royal Highness began to plan Madrasah Idrisiah as a center of learning for the people.

As a first step, the sultan relinquished 3 acres of land for the construction of the madrasa and erected five buildings, namely three teacher houses, an office (Rumah Bulat) and a master building (dormitories and classrooms). He also bestowed 23 shops in the town of Kuala Kangsar as the source of economy for school, for its expenses and to ensure that the Madrasah Idrisiah administration is able to run smoothly. The properties also covered the Masjid Ridzwaniah and the royal burial ground of al-Ghufran in Bukit Chandan. However, it was very unfortunate that the sultan could not see the completion of Idrisiah and the development of religious education that took place among the children of Malay Muslims, since he passed away in 1918. He was a lover of knowledge during his lifetime and he greatly honoured the ulama. Among the great scholars of his time were Haji Nawawi or Pak Wi, Tuan Yunus Malim Nawar and Tuan Haji Wan Muhammad, who was also the unofficial first mufti of Perak (Ahmad, 1998).

Following the death of the late Sultan Idris, all the duties and responsibilities of ensuring the continuation of this school were taken over by his son, Sultan Iskandar Qaddasallah Shah. He was responsible for overseeing the movement and construction of the madrasa until August 1921. Finally, in August 1922 Madrasah Idrisiah was complete, with 23 male orphans as the first batch of students (Yaacob, 2003).

Madrasah Idrisiah was built for a number of reasons, including to fulfill the will of the late Sultan Idris so that his wealth could be used to finance the administration and management of religious institutions in Perak. The main purpose in implementing the waqf was to protect, preserve and enhance Islam and its teachings in Perak. The properties were fully used for the construction of school dormitories and infrastructure. Apart from its close vicinity to the Istana Iskandariah, all matters and issues pertaining to the school can be addressed directly to the palace and the sultan may be kept informed of its progress from time to time.

Furthermore, the purpose of the establishment of Madrasah Idrisiah was also in line with the community's desire to see their children have a broad knowledge of the religion. With its construction, the will of al-Marhum Sultan Idris Mursyidul 'Adzam Shah, as well as the dream of the people, were achieved. Without the waqf property of the late sultan, it would have been impossible for Madrasah Idrisiah to exist. To reiterate, it was the bequest of the late sultan that enabled the establishment of the school. 
INTERNATIONAL JOURNAL OF ACADEMIC RESEARCH IN BUSINESS AND SOCIAL SCIENCES Vol. 10, No. 4, April, 2020, E-ISSN: 2222-6990 @ 2020 HRMARS

\section{The Ulama and Kaum Muda in the Development of Islamic Education}

Prior to the advent of Islam, the Jahiliya Arabs were known to vicious, ignorant and uncivilized. The arrival of Islam introduced the Arabs to the concepts of knowledge, teaching, writing, reading and pen (El-Muhammady, 1991). Islam arrived with the intention to change people's view of life and take them in a better direction. This is because the education system is closely related to knowledge and there is no escape from reading, investigation and research. The first revelation revealed to the Prophet Muhammad about 1400 years ago, surah al-Alaq, clearly shows that reading and knowledge are important. Knowledge in Islam aims to bring people to the truth in life, both in the world and in the hereafter. The absolute source of truth is God, the One who created that knowledge and truth.

In the context of Malaysian history, it is not too much to say that the development of a positive intellectual mindset that has been able to enlighten and generate more positive modernization stems from external influences (Rahim, 2001). The effectiveness of these external influences depends on the openness and willingness of the locals to adopt and adapt them to the local characteristics. In the Malaysian context, external influence can be traced to the religion of Islam itself (al-Attas, 1969). It can be seen from the beginning of the process of Islamization of the Malay world, when the conversion of a king was one of the major factors behind the speed of Islamization in the Archipelago. Much has been said about the conversion of a king to Islam and his role as the main reason behind the process of Islamization and the speed of its propagation (Abdullah, 2000).

In addition to the rapid development of Islamic educational institutions which fueled the intellectual development of the Malay community, the preservation of Islamic influence faced the challenge of colonialism which finally led to the development of the Islamic revival movement that had a profound effect on the Malay community (Rahim, 2000). This reciprocal process would continue in Malaysia as a result of the Malay community's acceptance of the concept of Ummah, which has been developed by the Islamic teachings (Rahim, 2002). The concept of Ummah is an important foundation that promotes the bonds of brotherhood that often exists between scholars, preachers and merchants of Islam (Abdullah, 2000).

At the beginning of the $20^{\text {th }}$ century, a new movement was initiated by those who have been educated in the Islamic education, especially those who received their education in Egypt. This movement is known as the islah movement (reformation), referring to a religious movement to eradicate the elements of shirk, superstitions and heresies among the Muslim community and to restore the teachings brought by Prophet Muhammad based on the Quran and Hadith (Yahaya, 1998). The propagation of this thought began when the newspaper al-Imam was published in 1906 and its existence was influenced by the al-Manar newspaper published in Egypt. Its publication seemed to attest to spread of polemic of thought - which had taken place in Egypt previous - in Malaya, with the existence of Kaum Tua (The Old Faction) and Kaum Muda (The Young Faction). Kaum Muda wanted reform while Kaum Tua are more comfortable with traditional Islamic practices in Malaya.

Based on author observation of the Islamic intellectualism in Malaya, it is not surprising that the trigger brought about by Kaum Muda, under the leadership of Sheikh Tahir Jalaluddin (18691956) and Syed Sheikh al-Hadi (1867-1934), resulted in sociocultural, political and economic changes of the Malays historical development. The period between the 1900 s and the 1940 s saw a striking contrast between the two main factions in providing the Malay with answers as to how Islam responds to the modernization brought by the British (Bakar, 1994). 
INTERNATIONAL JOURNAL OF ACADEMIC RESEARCH IN BUSINESS AND SOCIAL SCIENCES

Vol. 10, No. 4, April, 2020, E-ISSN: 2222-6990 @ 2020 HRMARS

The though development among the reformers in the Middle East had also influenced the young people in Malay Archipelago in general and in Malaysia in particular. Literature was among the vessel of Malay thought, which also played a significant role in changing the attitudes among young people, and there was resistance from the older generation who wanted to maintain the old thought values (Ismail, 2005).

For the Kaum Tua consisting of traditional ulama and the Malay aristocrats, in order to maintain the well-being of the Malay and Muslim community itself, we must consider the fact that modernization can be a dangerous process, and thus there was need to preserve the conventional way of life. In other words, Kaum Tua preferred that the Muslims return to the orthodox way of life and resist any forms of modernization (Bakar, 1994). Conversely, the Kaum Muda have been attuned to progressive thinking since the $20^{\text {th }}$ century and have greatly impacted the intellectual stream in Malaysia (Ismail, 2005). Understanding the elements of colonialization and globalization has shaped their thoughts when it comes to addressing the challenges faced by the Muslim Malays. Their ideas have been disseminated through the intellectual media, i.e the 'print nationalism' and became catalyst of a number of movements, NGOs and prominent Malay thinkers. Subsequently, these ideas have influenced modern political thought and given rise to the awareness of the progressive process of Islamization for cultural, social and political institutions.

Malay students studying in the Middle East in the late $19^{\text {th }}$ and early $20^{\text {th }}$ centuries were the ones with high initiative. This can be seen from their active involvement in union activities as well as publishing their own newspapers and forming printing companies to spread ideas that brought about awareness to the Malay community effectively. The roles played by al-Azhar University graduates and those who studied in Makkah were crucial in raising the Malay awareness before World War II. In addition to serving as a center for Malay education, it had also emerged as a center for the development of Malay intellectualism.

The authors are able to state here several factors that led to the intellectual movement of the Malay student at that time. First, it was due to the existence of printing centers that were printing books in Arabic and Malay for the use of the Malay community in the Hijaz and throughout the Malay Archipelago (Othman, 2006). The existence of printing centers played an important role as the printed books brought knowledge to the people. Second, exposure to the scholarly environment had also affected the development of the minds of Malay students who were in Makkah.

This can be seen from their reaction to issues that appeared in Malay newspapers and magazines of the time such as Tunas Melayu, Neracha, Idaran Zaman, Bahtera and Malaya. The students who studied there were not only regular readers and subscribers the newspapers but also contributed valuable ideas and insights to publications. With the existence of newspapers and magazines highlighting current issues in the Malay world, this had affected the students' thought development.

Therefore, it is clear that the influence that came from the Middle East also brought about social change in society when those educated in the region - and became known as the ulama pioneered the development of education for the Malay people. In addition to the Middle Eastern education that were shaping the intellectual culture, it was also a source of early Malay political consciousness. The evidence can be seen from the early influence of nationalism of the Malay people, which was Pan-Islamism that experienced rapid growth in Middle East, between the end of the $19^{\text {th }}$ century and early $20^{\text {th }}$ century (Saat, 2007). 
INTERNATIONAL JOURNAL OF ACADEMIC RESEARCH IN BUSINESS AND SOCIAL SCIENCES

Vol. 10, No. 4, April, 2020, E-ISSN: 2222-6990 @ 2020 HRMARS

Consequently, there were several Islamic movements that brought the idea of Islamic consciousness to their homeland. One of them was an alumnus of Madrasah Idrisiah and a student of Fahim (1870-1961), al-Baqir (1907-1974) who founded the Hisbul Muslimin on March 14, 1948. However, the organization was seen as a threat and the colonizers banned it in August 1948. It did not have the chance to establish itself in the Malaya since Hizbul Muslimin was accused of extremism. The British did not want to risk the chance that it will gather the support of the people and eventually achieve independence to form an Islamic nation.

The Key Ulama in the Islamic Education Development in Madrasah Idrisiah between 1922 until 1999.

Madrasah Idrisiah were administered by seven principals in the period of 1922-1999. While the Madrasah Idrisiah was still in its planning phase, Madrasah Mariah was first administered by Tuan Haji Nawawi b. Hajj Tahir, who was a significant figure in ensuring that His Majesty's wish to establish educational institutions such as Madrasah Idrisiah is achieved. Tuan Haji Nawawi was from Kedah and had continued his studies in Makkah. He was a teacher and religious advisor to Sultan Idris Shah. He was said to be the most influential person to the Sultan in the establishment of Madrasah Idrisiah. He was fondly known as Pak Wi. Upon receiving the order and consent from the Sultan Iskandar he was entrusted with the task of overseeing the process of establishing Madrasah Idrisiah. He had also contributed significantly to the religious education of the students of Madrasah Mariah (Bahari, 2003).

Mudir (principal) is a very important position in Islamic educational institutions especially religious schools. The personality of the mudir is the main yardstick in which a school's strength is measured. His knowledge, piety, good management skills and decisiveness are key factors in the school's progress. As such, the governing body of Madrasah Idrisiah made the effort to ensure the right candidate for the success of the mission and vision of the madrasa as expected by the palace. During the 77 years (1922-1999) there were seven mudir people who had served in this madrasa.

\section{Tuan Haji Muhammad Muhammad Haji Salleh (1922-1928)}

Immediately after Madrasah Idrisiah was officially established, Sultan Iskandar decreed that Tuan Haji Muhammad bin Haji Salleh should be the first mudir of Madrasah Idrisiah. He was from Kelantan and spent most of his life and education in Makkah. He was invited by Sultan Iskandar Shah to make plans to set up a madrasa and all administrative tasks were handed over to him to be managed properly and effectively. During his administration, he was assisted by two teachers, namely Tuan Habib bin Abdullah and Haji Othman Yaakub. It was with these three teachers that the students were able to successfully complete their education at this school. The first batch of students in 1922 was 23 orphans and all of them were male. There were not charged any fees. Within the first three years of its opening Madrasah Idrisiah only accepted orphans, and it was after that changes were made (Othman, 2006).

The first change made by the first mudir was to increase the number of intake which was previously restricted to orphans by opening the school to the public, although only male students were accepted still. This was due to the overwhelming demand from the people around Bukit Chandan and Kuala Kangsar, as the awareness of the importance of religious knowledge increased among the people. Haji Muhammad Haji Salleh served for six years and died in 1928. Even for a short 
INTERNATIONAL JOURNAL OF ACADEMIC RESEARCH IN BUSINESS AND SOCIAL SCIENCES Vol. 10, No. 4, April, 2020, E-ISSN: 2222-6990 @ 2020 HRMARS

time, Madrasah Idrisiah had accumulated great experience relating to enhancing potential and excellence as the first religious school in Perak. Haji Muhammad Salleh was a mudir who was deeply committed to his task and worked hard to develop the school. His effort became the turning point towards producing prominent scholars and leaders of the future (Bahari, 2003).

\section{Sheikh Abdullah Maghribi (1928-1932)}

The second mudir was Sheikh Abdullah Maghribi who succeeded Tuan Haji Salleh, and was in service from 1928 to 1932 (Bahari, 2003). He came from Makkah and was highly educated in religious studies and held a diploma in education. Prior to teaching in Madrasah Idrisiah, he was a teacher at Madrasah Al-Mashor, Penang. Under his leadership, Madrasah Idrisiah became more well-known and it was during this time that the first batch of students finally graduated from the school.

Sheikh Abdullah Maghribi was very concerned about the quality of his students' achievement. He made it compulsory for his students to pray with the congregation at the Masjid Mosque, which was located in front of the madrasa. In the time of Sheikh Abdullah Maghribi, the community began to see the potential of the students as most of these early students were offered the positions of cadi, religious officials and teachers in other newly opened madrasas. For the first time, Madrasah Idrisiah had opened a new era in history when Muslims could come and learn there. After the foundation of the madrasa was assigned to Tuan Haji Nawawi and the basic teaching was constructed by Tuan Haji Muhammad Haji Salleh, it was during Sheikh Abdullah Maghribi's time that the collective effort started to pay off.

The presence of Sheikh Abdullah Morocco in this madrasa introduced the ideas of 'Islah Islamiah', which was the Kaum Muda group. The Islah Islamiah movement was an attempt to purify the teachings of Islam that had been misinterpreted by ulama of the past. The movement seek to restore the position of Islam as an ad-din that embraces the whole spectrum of life, making Islam as the way of life (Mustajib, 1976).

At that time, the number of students in Madrasah Idrisiah increased to 150. As a result, the teaching force also expanded in order to accommodate the students. Among the newly appointed teachers were Sheikh Ali Maqsuri, Ustaz Abdul Razak and Ustaz Muhamnmad Fadzil, all of whom came from Penang with the exception of Ustaz Muhammad Nor Faiz who was from Perak. However, Sheikh Abdullah Maghribi' time as a mudir ended in 1932 because he had to return to Makkah due to several reasons. It was said that he quitted because his efforts were not approved by the school committee. This was due to his strict refusal to accept the bid'ah practices by the Malay community there and he was also accused of being a member of Kaum Muda who wanted to spread his ideology in the madrasa (Mustajib, 1976).

\section{Sheikh Abdullah Fahim (1932-1948)}

Between 1932 and 1948, Madrasah Idrisiah was administered by Sheikh Abdullah Fahim, or better known as Pak Him. He was the son of Tuan Haji Ibrahim, a well-known religious teacher in Makkah and the grandfather of Dato 'Seri Abdullah Badawi, former Prime Minister of Malaysia. From an early age, he was taken to Makkah by his father and received his religious education there. He was very well-educated in Masjidil-Haram, Makkah. Sheikh Abdullah Fahim was among the most prominent ulama of the $20^{\text {th }}$ century, on par with Tok Kenali of Kelantan (Ahmad, 1998). They happened to be 
good friends who exchanged letters on regular basis. Prior to starting his service in this madrasa, he taught at the Sekolah Arab Limbongan Kapal, Kedah and Dairatul Maarif Wataniah in Kepala Batas.

He was well-versed with 'Ilmu Falak' (Islamic Astronomy) and 'Hadith'. His expertise in both disciplines enabled him to fully understand the ideologies of Kaum Muda and Kaum Tua. According to him, what was important was not argument, correction or blame. Instead, the focus should be on the effort to disseminate adequate Islamic religious education through the self and establishment of more madrasas. He was also responsible for introducing the study of Ilmu Falak in Madrasah Idrisiah. His knowledge was so extensive when it came to the religion. He was said to be among the ulama who was able to produce the zij of falak syarie. He served for 16 years in the madrasa and during that time some of the most prominent ulama of Perak were produced, including Tuan Haji Asa'aya, the Fourth Mufti of Perak; Dato' Abu Hasan bin Abd. Majid, the Fifth Mufti of Perak; and Ustaz Haji Abu Bakar Al Baqir, an independence fighter and founder of Maahad Ehya II as-Syarif (Ghani, 2006).

While the previous intake was 150 students, during his time the number was 250, along with seven new teachers. He had doubled the efforts of previous mudir, making the madrasa among the most well-known in Malaya. It was also said that his method of teaching was through memorization. Sheikh Abdullah Fahim was an ulama with clear educational principles. He was constantly monitoring his students. For example, he often made surprise spot checks on the students in the dormitories who did not perform the Subuh prayers. He was very strict when it comes to student education and prioritized Islamic discipline in delivering his teaching. There were nine principles of his education (Ahmad, 1998):

i. Providing only the tahqiq interpretation of Quranic verses, based on major interpretation. All his students who were at higher level were encouraged to read the interpretations of AlBaidhawi, Al-Khazim, An-Nasafi and Ibn Abas. All new and old students were required to study the al-Jalalain Interpretation every day after Subuh and Maghrib prayers.

ii. Examining the hadiths through the muafiq and muqalaqah understanding.

iii. Following the matan of tauhid and fiqh. These were memorized and understood.

iv. Ensuring that tests in umumi were carried out alongside the teaching and learning.

v. Living the spirit of learning and teaching and putting the effort of learning and teaching as the main agenda and the most respected principle in life.

vi. Spreading the teachings of his books.

vii. Avoiding khilafiah issues when it comes to public understanding and practicing the opinions of Sunnah Wal Jamaah and the Shafie mazhab with regard to tauhid and figh.

viii. Making use of the vicinity of the mosque for spiritual exercise and worship training for students.

ix. Using Arabic textbooks in all Umumi subjects.

As such, he was widely respected for his reputation, not just in Perak, but also while he was in Penang. Due to his concern for his students' excellence, his relationship with the Perak sultan became the key factor for improving the quality of education of the madrasa under his leadership. Unfortunately, the glory of this madrasa as a center of great education was affected due to World War II. Madrasah Idrisiah suffered and its previously effective system was no longer as it used to be. 
INTERNATIONAL JOURNAL OF ACADEMIC RESEARCH IN BUSINESS AND SOCIAL SCIENCES Vol. 10, No. 4, April, 2020, E-ISSN: 2222-6990 @ 2020 HRMARS

\section{Tuan Sheikh Haji Az-Zubair Haji Ahmad (1948-1976)}

As a result of the retirement of Sheikh Abdullah Fahim Haji Ibrahim, Madrasah Idrisiah lost a scholar of caliber who brought about an era of excellence to the madrasa. For several months Madrasah Idrisiah had no driver. Finally, there was an ulama how had just finished his studies in the holy land of Makkah. The Madrasah Idrisiah governing committee agreed to the Sultan's decision to appoint Tuan Sheikh Az-Zubair to be the fourth mudir starting in 1948. With his experience and role of opening a school in Makkah, he was expected to bring Madrasah Idrisiah to greater prominence, especially with the madrasa under the patronage of the sultan (Ahmad, 1998).

Sheikh Az-Zubair became the one who brought back the golden age of Madrasah Idrisiah as once done by Sheikh Abdullah Fahim. He was the longest serving mudir in Madrasah Idrisiah, with a period of almost 28 years. His love for Madrasah Idrisiah was so great that he willed a part of his property in Teluk Intan for the orphans in Madrasah Idrisiah. He was of gentle predisposition, but could be very strict and fearless at other times. He was also active in the Al-Ihya movement between 1947 to 1948 (Abdullah, 1976). As with previous principals, he was very strict in matter pertaining to Islamic practices, especially praying in congregation in Masjid Ubidiah.

A firm approach with regard to praying in congregation was factor for parents to send their children to Madrasah Idrisiah. Parental response to this madrasah was very encouraging. In 1966 there were about 385 students. His strictness became the talk of the people, especially by students who did not perform prayers in congregation. During the reign of Sultan Yusof Izzuddin Shah (19481963), the $32^{\text {nd }}$ Sultan of Perak, he instructed Tuan Sheikh Az-Zubair to come before him, on complaints that Sheikh Az-Zubair had beaten his students for not praying in congregation. However, the explanation given by Sheikh Az-Zubair led Sultan Yusof to raise his monthly salary by fifty ringgit (Zainuddin, 2000). His firm attitude contributed to the fame that Madrasah Idrisiah was enjoying.

During the reign of Sultan Yusuf, he was very concerned about the performance of Madrasah Idrisiah. His attentive attitude can be seen from his monetary contribution to the madrasa whenever he celebrated his birthday. He would unfailingly invite the madrasa students to his banquet at Istana Iskandariah. 1960s saw Madrasah Idrisiah continuing under the leadership of Sheikh Az-Zubair. Sheikh Az-Zubair ran various co-curriculum programs, including sports and clubs. For example, public speaking was introduced to sharpen the leadership talent of his students. Although most of the subjects in Madrasah Idrisiah were taught in Arabic, English language was also given priority. For the purpose of improving English language skills among the students, activities for language week such as lectures and public speaking were held. The contribution and role played by Sheikh Az-Zubair were meaningful and deserves high praise.

It was during this time that discussions to hold academic classes for students started to take place, so that the students would be on the same level as the ones in government-run schools. Various discussions took place, to ensure the implementation of the academic subjects. The matter was debated in the Al-Marhum Sultan Idris Waqf Trust Board meeting after demands were made by the students. In response to the demands, a proposal was drafted to implement the teaching of academic subjects along with Arabic and religious studies. In 1975, the Madrasah Idrisiah Committee agreed to the idea with the implementation to take place during the third semester of the year. The committee also requested an allocation of RM 3000 from Religious Trustees and Khairat Al-Marhum Sultan Idris to implement the educational program. The academic education program was 
implemented in order to meet the aspirations of the students and to align with the mainstream national education (Ahmad, 1998).

Towards the end of his career at Madrasah Idrisiah, the number of students enrolling had decreased. Although efforts were made to restore the Idrisiah Madrasah, they were unsuccessful. The Golden Jubilee celebration as a remedial effort did not receive the expected response from the madrasa governing body. The alumni association who had once applied for a meeting in 1974 was rejected by the administrative body at that time. The period of decline continued from 1976 to 1985. The Ihtifal Ceremony or presentation of awards and certificates that was held annually to honor outstanding students did not take place from 1972 to 1985.

In this context, the role of the sultan is crucial to the development of the Madrasah Idrisiah. Whenever the Ihtifal Ceremony was held, the sultan who sat on the throne would be there to present the awards. This tradition continued until the reign of Sultan Yusuf Izzuddin Shah (1948-1963). During the reign of Sultan Idris Shah (1963-1984), he participated only once in the official ceremony of the Madrasah Idrisiah, which was the Golden Jubilee in 1972. This situation shows that the role of sultan and ulama have always been important to the development of the madrasa. Sheikh Az-Zubair finally resigned in 1976, due to health problems, which made it difficult for him to continue as the mudir of the school.

\section{ato 'Haji Abu Hassan bin Abdul Majid (1976-1983)}

The next mudir of Madrasah Idrisiah was a mufti of the state, Dato 'Haji Abu Hassan bin Abdul Majid. He was the former Perak mufti, and a member of Madrasah Idrisiah Administrative Committee at the time. He was appointed as the fifth mudir from 1976 to 1983. He sought to revive Madrasah Idrisiah, but his efforts were futile. Attempts to attract female students were made but received little response. Tuan Haji Abu Hassan bin Abdul Majid was unable to make much change due to his poor health. After six years of service he finally resigned. At this point, it appeared that Madrasah Idrisiah was no longer the concern of the government nor the sultan. The number of students continued to decline until only 30 were left. The deterioration that occurred during that time was due to Dato 'Haji Abu Hassan bin Abdul Majid's illness and there was no successor to replace him, as well as problems within the administration of the madrasa. For that reason, many parents decided to send their children to other schools in Perak (Ahmad, 1998).

\section{Tuan Haji Nawawi bin Hassan (1983-1985)}

Following the resignation of Tuan Haji Abu Hassan, the administration appointed Tuan Haji Nawawi bin Hassan (1983-1985) as the sixth mudir of Madrasah Idrisiah. It was hoped that as an alumnus of the school he would be able to bring the much needed change to Madrasah Idrisiah. As such, he made attempts to improve the quality and performance of the Idrisiah Madrasah. Due to financial constraints, changes were not possible. Tuan Haji Nawawi introduced academic subjects into the school curriculum in Madrasah Idrisiah. For the first time, he opened the doors to female students. The weekends were changed from Friday to Saturday and Sunday. However, the anticipated changes did not happen because in 1985 , he passed away. The attitude displayed by the administrators was the factor that led to the deterioration of Madrasah Idrisiah. The role of the current sultan was not directed towards resolving problems. The problems continued, leading to the eventual deterioration 
INTERNATIONAL JOURNAL OF ACADEMIC RESEARCH IN BUSINESS AND SOCIAL SCIENCES Vol. 10, No. 4, April, 2020, E-ISSN: 2222-6990 @ 2020 HRMARS

of Madrasah Idrisiah, while His Royal Highness the Sultan of Perak, Sultan Idris Shah II did not provide the support and encouragement as the sultans who came before him did.

Generally, the ruling sultan of Perak would continue to provide support and encouragement for mudir or ulama so that they can perform their respective roles effectively. The situation then can be a demotivating factor for the committee members' desire to find solutions to the revival of Madrasah Idrisiah. The physical state of the school buildings, which were getting old themselves, seemed to be a metaphor that Madrasah Idrisiah might not ever return to its glorious days. However, things began to change when His Majesty the Sultan of Perak, Sultan Azlan Muhibbudin Shah succeeded the throne on February 3, 1984 (Abdullah, 1999).

\section{Ustaz Musa Bin Zainuddin (1985-1999)}

Ustaz Musa began his service on June 1, 1985, after he received the decree from the Sultan of Perak Sultan Azlan to become the seventh mudir of Madrasah Idrisiah. Prior to his tenure, he served as the Information and Dakwah Supervisor at JAIP. An avid writer, he revived the monthly magazine published by Perak Islamic Religious Council (JAIP) under the new name 'Suara Majlis'. He was also involved as one of the writers for other earlier magazines such as Seruan Majlis and ar-Ridzwan. After the publication of the two magazines was discontinued, Suara Majlis returned to the public on October 18, 1982 and he was its Chief Editor until the early 1990s (Bahari, 2003).

After he was appointed, Ustaz Musa and other members of Board of Directors, teachers and staff were committed to restoring the religious institution. Thanks to all the hard work and dedication, Madrasah Idrisiah was able to generate significant growth over the next 10 years. During that time six buildings were erected, with a total cost of RM 4 million.

It can be said that the developments that took place between 1922 and 1985 showed how the sultan and ulama were significant in ensuring the continuous progress of Madrasah Idrisiah Madrasah, Bukit Chandan Kuala Kangsar Perak. Authoritative ulama and the role of the sultan were the main focus when it comes to development of Islam in Perak. As we can see from 1922 to 1985, the development can be divided into three stages, namely, the establishment, the glory and the decline. The period from 1985 to 1999 can be viewed as the revival period and efforts towards this reform had been made by Ustaz Musa bin Zainuddin himself, the seventh mudir of Madrasah Idrisiah.

\section{Conclusion}

In the Malaysian context and the part of the Islamic culture, Islamic studies become more important because of the religion Islam itself as expressed in the constitution, in the religion of the federation. Malaysia is an Islamic country thus the purpose of the establishment of Islamic studies is to sharpen the leadership skill through religious studies and the strengthened relationship between fellow students and lecturers of conventional and Islamic in Malaysia. Besides, religious elites have significant contributions to make in the conception and execution of development programs in developing countries like Malaysia. Government and higher institution acknowledges the enormity of the task of universal access to good quality education at the basic level, and know that its execution would have to be a partnership with all levels of civil society.

The leadership of the ulama as the ummah leader cannot be underestimated. This is because of the effort that they have been making to assist the Ummah in various times and situations, and this includes Madrasah Idrisiah. The development from 1922 until Independence has shown how 
INTERNATIONAL JOURNAL OF ACADEMIC RESEARCH IN BUSINESS AND SOCIAL SCIENCES Vol. 10, No. 4, April, 2020, E-ISSN: 2222-6990 @ 2020 HRMARS

sultans and ulama played a significant role in the development of madrasa. Ulama and sultan are important components of Islamic development in Perak, especially about the oldest madrasa in the state. Serious attention that was given by the sultan and the ulama who were the mudir of the school had enabled the production of prominent figures in the society. Thanks to the determination and perseverance of the scholars who governed and educated the students before the Independence, the students then moved on to become ulama and leaders themselves. This clearly shows that the relationship between ulama and sultans is very important in enhancing Islamic knowledge through the Islamic Education system as introduced in this madrasa.

The role played by the ulama in the state of Perak is of no minor significance. They have made every effort to be involved in helping the community. Although some of them have been accused of resisting the Western colonizers, it did not dampen their efforts to impart knowledge. Their love for knowledge has had a profound effect on the development of madrasas, especially Madrasah Idrisiah, which is still renowned to this day.

\section{Corresponding Author}

Mohd Farhan Abd Rahman, Academy of Contemporary Islamic Studies (ACIS), Universiti Teknologi MARA Perak Branch, Seri Iskandar Campus, 32610 Seri Iskandar, Perak, Malaysia

Email: farhan84@uitm.edu.my.

\section{References}

Abdullah, A. (2000). Kerajaan Melayu: Sendi Islam dalam Pemerintahan Tradisi. In Tamadun Islam di Malaysia. Kuala Lumpur: Dewan Bahasa dan Pustaka

Abdullah, A. V. T. (1999). Adat Pusaka Raja-raja dan Orang Besar-besar Negeri Perak Darul Ridzuan. Ipoh: Compass Life Sdn. Bhd

Abdullah, N. (1976). Maahad II Ihya Assyariff Gunung Semanggol 1934-1959. Bangi: Jabatan Sejarah Universiti Kebangsaan Malaysia.

Adil, B. (1972). Sejarah Perak. Petaling Jaya: Percetakan Abadi

Ahmad, T. S. (1998). Madrasah Idrisiah Kuala Kangsar: Satu Kajian dari Segi Sejarah Penubuhan dan Sumbangannya Terhadap Pendidikan Islam. Academic Exercise. Universiti Kebangsaan Malaysia, Bangi.

Al-Attas, S. M. N. (1969). Preliminary Statement on A General Theory of the Islamization of the MalayIndonesian Archipelago Kuala Lumpur: Dewan Bahasa dan Pustaka

Bahari, M. A. (2003). Madrasah Idrisiah Tahun 1922 hingga 2000: Peranan Sultan dan Ulama Terhadap Penubuhan dan Perkembangannya. Thesis Universiti Kebangsaan Malaysia.

Bakar, I. A. (1994). Islamic Modernism in Malaya: The life and Thought of Sayid Syekh al-Hadi 18671934. Kuala Lumpur: Penerbit Universiti Malaya.

El-Muhammady, A. H. (1991). Pendidikan Islam (Falsafah, Disiplin \& Peranan Mendidik). Kuala Lumpur: ABIM.

Emerson, R. (1982). Malaysia: Satu Pengkajian dalam Pemerintahan Sechara Langsung dan Tidak Langsung. Kuala Lumpur: Dewan Bahasa dan Pustaka

Ghani, Z. A., Talib, O., Zain, F. M., \& Jamsari, E. A. (2006). Syeikh Abdullah Fahim Ulama Melayu Progresif. Bangi: Fakulti Pengajian Islam, Universiti Kebangsaan Malaysia. 
INTERNATIONAL JOURNAL OF ACADEMIC RESEARCH IN BUSINESS AND SOCIAL SCIENCES

Vol. 10, No. 4, April, 2020, E-ISSN: 2222-6990 @ 2020 HRMARS

Ismail, H. (2005). Kaum Muda dan Pemikiran Progresif di Malaysia. In Hamdani, H. (ed.). Islam di Malaysia dan Sastera Nusantara. Kuala Lumpur: Gapeniaga Sdn. Bhd.

Mustajab, M. S. (1976). Syeikh Abdullah Maghribi: Pendidikan dan Kaum Muda. In Jebat, No. 5/6: 16.

Nor, A. R. N. (2000). Jurnal Khas Madrasah Idrisiah 2000. Kuala Kangsar: Penerbit Madrasah Idrisiah.

Othman, M. R. (2006). Islam dan Masyarakat Melayu: Peranan dan Pengaruh Timur Tengah. Kuala Lumpur: Penerbit Universiti Malaya.

Rahim, R. A. A. (2000). Kebudayaan Melayu dan Islam di Nusantara: Satu Analisa Pengkaedahan. In Seminar Hukum Islam Semasa 111 Peringkat Kebangsaan 2000. Organised by Jabatan Fiqh dan Usul Akademi Pengajian Islam, Universiti Malaya on 7-8 November 2000.

Rahim, R. A. A. (2001). Al-Quran Dan Pemodenan Di Alam Melayu : Satu Analisa. In Seminar Warisan Al-Quran Peringkat Kebangsaan 2001. Co-organised by Pusat Ilmu Kemanusiaan Universiti Sains Malaysia and YADIM on 24-25 October 2001.

Rahim, R. A. A. (2002). Dakwah dan Jalinan Intelektual di Rantau Alam Melayu-Indonesia: Satu Analisa Sejarah. In Seminar Antarabangsa Pengajian Dakwah Indonesia-Malaysia. Co-organised by Universitas Muhammadiyah Sumatera Utara and Fakulti Pengajian Islam Universiti Kebangsaan Malaysia, on 18 May 2002.

Saat, I. (2007). Sejarah Politik Melayu Pelbagai Aliran. Shah Alam: Karisma Publications Sdn. Bhd.

Yaacob, R. L. M. (2003). Madrasah Idrisiah: Sejarah Penubuhan, Peranan dan Sumbangannya Terhadap Masyarakat Setempat. Academic Exercise. Jabatan Sejarah dan Tamadun Islam Akademi Pengajian Islam, Universiti Malaya.

Yahaya, M. (1998). Abu Jabir Abdullah bin Ahmad al-Ghadamisi: Tokoh Ulama Islah di Tanah Melayu. In Sejarah dan Proses Pemantapan Negara-Bangsa. Prosiding Kongres Sejarah Malaysia Kedua, vol. 2.

Zainuddin, M. (2000). Idrisiah 63 Tahun Yang Saya Ketahui. In Jurnal Khas Madrasah Idrisiah 2000. Kuala Kangsar: Penerbit Madrasah Idrisiah. 